\title{
THE ATTENTIONAL SYSTEM IN THE CASE OF HARVEY WEINSTEIN SEXUAL ABUSE ALLEGATIONS ON INTERNATIONAL ONLINE NEWS
}

\section{Rudi Suherman}

Univesitas Persatuan Islam, Bandung, Indonesia

Email: rudipipit11@gmail.com

\begin{abstract}
The study aims to find out the attention system, especially, the focus of attention patterns, on news articles related to the Harvey Weinstein sexual harassment allegations case. Qualitative descriptive methods were used in this study. The data was taken from the BBC and the stylist's broadcasting article about the case. The results show that the figure-ground organization as an element in the focus of attention patterns is mapped and clearly constructed. Weinstein, who fits the role of the perpetrator, reasoned on the victim and the attention of the news writer's article that formed the ground, while the victim and other entities set the ground in the sentence. This reasoned and background phenomenon shows that the cognition of victims and news writers places more attention and perception on perpetrators than other entities.
\end{abstract}

Keywords: attentional system; focus of the attention; sexual abuse allegation

Coresponden Author

Email: rudipipit11@gmail.com Artikel dengan akses terbuka dibawah lisensi

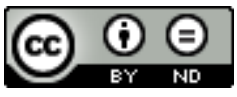

\section{Introduction}

Cognitive linguistics is part of modern school of linguistics. It is believed to be the most exciting approach to discuss about language and thought (Coulson and Oakley 2005). Since it is based on thought, Cognitive linguistics s highly relied on people's model of memory, attention and perception which is represented to utter language in written or spoken (Evans 2007).

In addition to this, (Evans 2006) state that cognitive linguistics is a movement or an enterprise because it is on specific theory. Instead, it is an approach that has adopted a common set of guiding principles, assumption, and perspective which have led to a diverse range of complementary, overlapping (and sometimes competing) theories. Since it is study about human's thought (Reeves and Rowe 2002). Every form of language artefact produced by human can be analyzed and studied by cognitive linguistics (Ormston et al. 2014). 
People's cognition conveys certain messages. Linguistically, This Message can be manifested into two different form orally and in written. The later has variety of form such as memo, letter, newspaper, magazine, and story (Grabe and Kaplan 2014). Each type of written form serves different social function. Newspaper as of the form of mass media serves its function to broadcast certain information to be read or known by certain society.

People nowadays are getting more exposed to what we call as mass media especially electronic media. It is included newspaper or magazine or it is called as epaper. This platform of mass media provides variety of the information either old or the current phenomena that takes place around the world electronically. That information can be easily accessed by our mobile phone. We can exactly trace about what happening is in the world from the trivia information serving as the 'light meal' for the readers up to the vital information that draw much attention due to its impact.

As one of language product, newspaper always represents the writer or contributors' cognition toward certain things. It may represent their cognition, attention or perception (Olson 1996). Through cognitive linguistics study, readers are able to see how the author, or language producer in mass media craft their embodied experience in linguistic representation (Burgess 1990). Specifically, the attentional system which is recognized as one feature in cognitive linguistics is able to view people's attention over matter and action (scene and their participants) (Ungerer and Schmid 2013).

One of the current cases that has drawn public attention in online media is Weinstein sexual abuse allegation. Weinstein is eminent American film producer. He is highly respectable producer in Hollywood industry. Unfortunately, In October 2017, the New York Times and the New Yorker reported that more than a dozen women accused Weinstein of sexually harassing, assaulting, or raping them. Many other actresses in the film industry subsequently reported similar experiences with Weinstein. This scandal has shaken the Hollywood industry. As a result of these accusations, Weinstein stepped down from his production house company, and several projects which were involved him have to be cancelled or suspended.

This case gained excessive publication worldwide, many mass media reported this including BBC news and STYLIST. Two of among his victim are the Lena Headey and Kate Beckinsale. The two famous Hollywood actresses have admitted as Weinstein's victim. They both told how the unwanted case happened to them. Their testimonies on social media are cited by BBC and STYLIST and gain public attention.

This study is trying to analyze the attentional system of those two actresses as victim, and the article author related to the case of sexual scandal which is involved Harvey Weinstein.

\section{Method}

Qualitative descriptive method is employed in this study (Sugiyono 2011). Qualitative research assumes that all knowledge is relative, that there is subjective element to all knowledge and research and that holistic ungeneralizable studies are 
justifiable (Sujatna, Heriyanto 2016). The aim of descriptive study is to describe certain condition or phenomena scientifically. In that case, it aims to describe the schematic type, particularly, the attentional system that are found in 2 different articles taken from BBC News and STYLIST magazine.

In addition to descriptive, this article discusses and analyzes the victim and the article author's nature of attention which is realized in form of linguistic representations (Creswell 2016). It also views windowing and gapping or eliminated information from the text and their implication toward the news. After the data are classified. They are then analyzed to find the reason why certain entities or participants are being more foregrounded than the others.

\section{Analysis and Discussion}

The data taken from the BBC and STYLIST articles related to the media covered on the issue of sexual allegation are collected. These data show several insightful findings that worth discussing. The data analysis and discussion are shown as follows.

Table 1

The Attentional Pattern in Two Different News

\begin{tabular}{|c|c|c|c|}
\hline No. & Data & Article title & Source \\
\hline 1 & $\begin{array}{l}\text { The Hollywood mogul was "furious "after } \\
\text { she resisted his sexual advance. She details } \\
\text { in a series of twitter posts }\end{array}$ & $\begin{array}{lr}\text { Weinstein } & \text { Scandal: } \\
\text { Game of } & \text { Thrones } \\
\text { actress } & \text { "felt } \\
\text { powerless } & \\
\end{array}$ & $\begin{array}{lr}\text { BBC } & \text { News accessed } \\
\text { On } & \text { December,20 } \\
2017 & \end{array}$ \\
\hline 2 & $\begin{array}{l}\text { The British actress joins a list of over } 40 \\
\text { women who have accused the producer of } \\
\text { the misconduct. }\end{array}$ & & \\
\hline 3 & $\begin{array}{l}\text { He has been accused of rape, sexual assault } \\
\text { and harassment but has "unequivocally } \\
\text { denied "any allegation of non - consensual } \\
\text { relationships. }\end{array}$ & & \\
\hline 4 & $\begin{array}{l}\text { Headey described sharing a lift with } \\
\text { Weinstein after he had invited her to his } \\
\text { room to show her a script }\end{array}$ & & \\
\hline 5 & $\begin{array}{l}\text { He added Weinstein had been protected by } \\
\text { other men around him. }\end{array}$ & & \\
\hline 6 & 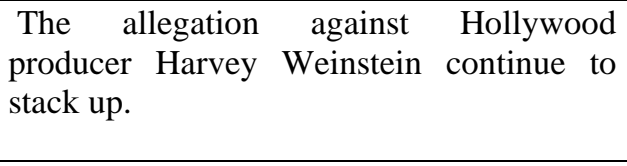 & $\begin{array}{l}\text { Kate Beckinsale: } \\
\text { Weinstein "couldn't } \\
\text { remember "if he'd } \\
\text { assaulted me }\end{array}$ & $\begin{array}{l}\text { STYLIST, accessed } \\
\text { on December, } 23^{\text {rd }} \\
2017 \text {. }\end{array}$ \\
\hline 7 & $\begin{array}{l}\text { Kate Beckinsale is one of the latest to say } \\
\text { she has had disturbing experiences with the } \\
\text { film mogul. }\end{array}$ & & \\
\hline 8 & He opened the door in his bathrobe. & & \\
\hline 9 & he's an actual predator. & & \\
\hline
\end{tabular}

It can be seen from the table above, there are nine different data taken from 2 different online news, BBC and STYLIST. There are 4 data found in BBC news, and 
there are 4 data found in STYLIST. To gain profound understanding about the data finding, some representative data are analyzed. There are five data that are discussed and interpreted using attentional system model. The data are analyzed on the following analysis.

Datum 1: The Hollywood mogul was "furious "after she resisted his sexual advance. She details in a series of twitter posts (BBC News: Weinstein Scandal: Game of Thrones actress "felt powerless. October, 17 2017)

The first datum is taken from the first news. It illustrates a focus of attention pattern. The Hollywood mogul corresponding to the perpetrator role is fore- grounded. In other words, it become figure. The rest of the sentence including the victim, 'she ', roles are backgrounded and together make up the ground. In term of strength of attention, the foregrounding results from mapping of attention onto particular entities in the case.

The lexical selection of Hollywood mogul as an replacement of "Harvey Weinstein " has constructed strong image that refers to him as an important person who has great wealth and power in Hollywood film industry. In addition, the phrase is collocated with a word furious. Which meaning extremely angry. This grammatical construction has created the impression toward the reader that the case is serious case involving highly power person.

Datum 2: He has been accused of rape sexual assault and harassment but has "unequivocally denied "any allegation of non - consensual relationship. (BBC News: Weinstein Scandal: Game of Thrones actress "felt powerless. October, 17 2017).

The second datum is taken from the first news. It illustrates a focus of attention pattern. The passivization is created in the clause. The pronoun he is backgrounded, since passive sentence is chosen as the grammatical construction there. The he corresponding to the perpetrator role is fore-grounded (Tan 2011). In other words, it become figure. The rest of the sentence are backgrounded and together make up the ground. In term of strength of attention, the foregrounding results from mapping of attention onto particular entities in the case.

The passive sentence has implied the choice over which participant in the event is placed. The perpetrator, Weinstein, explicitly mention as the scene (windowing), while other parts, in this case the women who reported Weinstein is omitted (Gapping). This linguistic representation has driven the readers to pay their attention to the perpetrator rather than the victim.

Datum 3: He added Weinstein had been protected by other men around him. (BBC News: Weinstein Scandal: Game of Thrones actress "felt powerless. October, 17 2017) 
The third datum is taken from BBC News article. It contains a focus of attention pattern. Attention pattern is similar to the previous datum. It illustrates a focus of attention pattern. The passivization is created in the clause. Pronoun he was backgrounded, since passive sentence is chosen as the grammatical construction there. The he corresponding to the perpetrator role is fore-grounded. In other words, it become figure. The rest of the sentence are backgrounded and together make up the ground. The In term of strength of attention, the foregrounding results from mapping of attention onto particular entities in the case.

The passive sentence has implied the choice over which participant in the event is placed. Weinstein who explicitly mention as the scene (windowing), while other parts, in this case the powerful people who protect him is omitted (Gapping). This linguistic representation has driven the readers to pay their attention to the perpetrator rather than the victim. In addition to this (Branigan and Pickering 2017). The author of the news wants to conceal those who protect Harvey Weinstein. He/she may avoid the risk by not revealing the protectors' identity that may harm his/her career.

Datum 4: The allegation against Hollywood producer Harvey Weinstein continue to stack up. (STYLIST: Kate Beckinsale: Weinstein "couldn't remember " if he'd assaulted hem , October, 262017 )

The fourth datum is an active clause. It illustrates figure - ground organization the allegation is foregrounded, in other words, it is the figure. This can be seen from the presence allegation as the nominalization of the verb to allege. Hence the allegation is embedded to certain entity as the figure which does not include in the clause. Which means there are people who allege Weinstein for sexual abuse. Harvey Weinstein, corresponding to the accused, is backgrounded and together with the rest of the clause make up the ground.

This linguistic representation has driven the readers to pay their attention to what the producer rather than those who report him for his act. In addition to this, the writer writes the article using present tense and select the verb "continue". This grammatical construction has created meaningful message to the reader that the case is relatively new and is still taking place (Rumelhart 1976).

Datum 5: He opened the door in his bathrobe. (STYLIST: Kate Beckinsale: Weinstein “couldn't remember "if he'd assaulted me, October, 26 2017).

The fifth datum is taken from people news. It has figure - ground Organization. $\mathrm{He}$, corresponding to Perpetrator role, is fore-grounded. In other words, it is figure. The door and the rest of the clause roles are backgrounded and together make up the ground. Hence, the datum illustrates a focus of attention pattern. In term of strength of attention, the foregrounding results from mapping of attention onto particular entity in the scene. 
The lexical selection of" bathrobe" as an exchange of among other clothes-related vocabulary has evoked a schematic image to the readers. The lexical bathrobe refers to a condition of the user. He may just finish taking a bath or is about to do it. In addition, bathrobe is unusually attire when welcoming a guest. It may also refer to a symbol of sexual seduction to particular culture. In addition to this, the use of the present tense in the clause has evoked the readers 'attention that event is recently happened.

\section{Conclusion}

The result of this research shows that the attentional system is found in the case of Harvey Weinstein sexual abuse allegation. The figure - ground organization which rises from focus attention pattern are vividly constructed. This condition reflects the nature of author or victim's perception toward the case in which Weinstein, corresponding as the perpetrator role, is fore- grounded making up the ground, whereas the victim and other entities are backgrounded creating the ground in the sentence. It concludes that either the victim or the author's cognition pay more their attention to Weinstein as the perpetrator rather than to other entities. 


\section{BIBLIOGRAFI}

Branigan, Holly P., and Martin J. Pickering. 2017. "An Experimental Approach to Linguistic Representation." Behavioral and Brain Sciences 40.

Burgess, Jacquelin. 1990. "The Production and Consumption of Environmental Meanings in the Mass Media: A Research Agenda for the 1990s." Transactions of the Institute of British Geographers 139-61.

Coulson, Seana, and Todd Oakley. 2005. "Blending and Coded Meaning: Literal and Figurative Meaning in Cognitive Semantics.” Journal of Pragmatics 37(10):1510 36.

Creswell, John W. 2016. "Research Design: Pendekatan Metode Kualitatif, Kuantitatif, Dan Campuran.” Yogyakarta: Pustaka Pelajar 5.

Evans, Vyvyan. 2006. Cognitive Linguistics. Edinburgh University Press.

Evans, Vyvyan. 2007. Glossary of Cognitive Linguistics. Edinburgh University Press.

Grabe, William, and Robert B. Kaplan. 2014. Theory and Practice of Writing: An Applied Linguistic Perspective. Routledge.

Olson, David R. 1996. The World on Paper: The Conceptual and Cognitive Implications of Writing and Reading. Cambridge University Press.

Ormston, Rachel, Liz Spencer, Matt Barnard, and Dawn Snape. 2014. "The Foundations of Qualitative Research." Qualitative Research Practice: A Guide for Social Science Students and Researchers 2:52-55.

Reeves, Colin, and Jonathan E. Rowe. 2002. Genetic Algorithms: Principles and Perspectives: A Guide to GA Theory. Vol. 20. Springer Science \& Business Media.

Rumelhart, David E. 1976. Toward an Interactive Model of Reading. Center for Human Information Processing, University of California San Diego ....

Sugiyono, Prof. 2011. "Metodologi Penelitian Kuantitatif Kualitatif Dan R\&D." Alpabeta, Bandung.

Sujatna, Heriyanto, Kasno Pamungkaas. 2016. "Trope And Pictorial Metaphor: Figures Of Speech And Visual Methapor Analysis In Nature Tourism Object Promotion Of West Java - Indonesia. IJASOS,Vol.II ,Issue 4, April 2016.”

Tan, Sabine. 2011. "Facts, Opinions, and Media Spectacle: Exploring Representations of Business News on the Internet.” Discourse \& Communication 5(2):169-94.

Ungerer, Friedrich, and Hans-Jorg Schmid. 2013. An Introduction to Cognitive Linguistics. Routledge. 